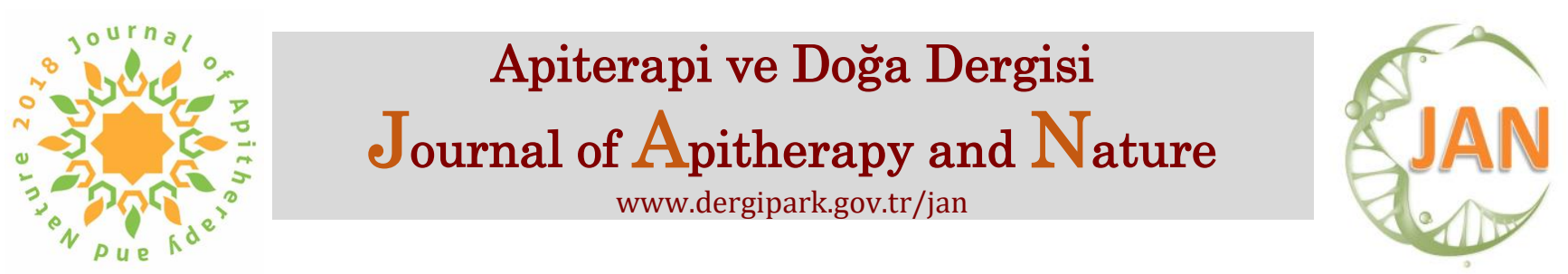

\title{
A study Concerning the Black Sea Region Teas: Quality Parameters and The Possibility of Conversion to The New Products by $R \& D$
}

\section{Karadeniz Bölgesi Çayları Üzerine Bir Araştırma: Kalite Parametreleri ve Ar-Ge ile Yeni Ürünlere Dönüşme Olanakları}

\section{Gulsum Merve BOYRACI*}

\author{
Department of Food Processing, Macka Vocational School, Karadeniz Technical University, Trabzon, 61080, Turkey \\ merveturkut@ktu.edu.tr, ORCID: 0000-0002-6036-8072
}

Received/Geliș Tarihi: 26/05/2020, Accepted/ Kabul Tarihi: 24/08/2020

*Corresponding author/Yazışılan yazar

\section{Abstract}

The tea plant is one of the most consumed as beverages in the world's oldest and widely which ranks second after water among non-alcoholic beverages. Our country is 7 th in terms of agricultural areas allocated to tea plant (Camellia sinensis, L), and it is 5th in dry tea production in the World. Consuming so much tea has led scientists to investigate the effects of tea on health. These studies have shown that bioactive components in the tea have antimutagenic, anticarcinogenic, antibacterial, antiallergic and antioxidant properties. Tea is an important agricultural product in the Eastern Black Sea Region and employs approximately 22500 families. However, in our country, tea is consumed only as a beverage and as a small amount of by-products. The rich bioactive content of tea is too much to be underestimated. Also, considering the production of tea in our country, it is seen that it does not create enough added value and it does not one of the non-tea product's market.

For this reason, the aim of this study is to introduce the quality of the regional teas and to evaluate the processability of the non-tea doi: 10.35206/jan.742930

e-ISSN: 2667-4734

\section{Özet}

Çay bitkisi, dünyanın en eski ve yaygın olarak en çok tüketilen içeceklerinden birisi olup alkolsüz içecekler arasında sudan sonra ikinci sırada yer almaktadır. Ülkemiz çay bitkisine (Camellia sinensis, L) ayrılan tarım alanları bakımından Dünya'da 7. sirada iken, kuru çay üretiminde 5. sırada yer almaktadır. Çayın bu kadar çok tüketilmesi bilim insanlarının çayın sağlık üzerine etkilerini araştırmaya yöneltmiştir. $\mathrm{Bu}$ çalışmalar çaydaki biyoaktif bileşenlerin antimutagenik, antikarsinojenik, antibakteriyel, antialerjik ve antioksidan özelliklerinin olduğunu göstermiştir. Doğu Karadeniz Bölgemizde çay önemli bir tarım ürünü olup yaklaşık 22500 aile istihdam sağlamaktadır. Buna karşın ülkemizde çay, sadece içecek olarak ve çok az miktarda yan ürüne işlenmesi şeklinde tüketilmektedir. Çayın zengin biyoaktif içeriği küçümsenmeyecek kadar çoktur. Ayrıca ülkemizdeki üretimi göz önüne alındığında yeteri kadar katma değer yaratılmadığı ve çay dışı ürünler pazarında yer almadığı görülmüştür.

$\mathrm{Bu}$ nedenle çalışmamızda üretimi ile dünyada ilk sıralarda yer aldığımız ve halkımız 
products other than drinking tea which is in the first place in the world and provide important employment for our people.

Keywords: Tea, Tea quality, Eastern Black Sea Region, Value added

\section{Abbreviations:}

için önemli bir istihdaam sağlayan bölge çaylarının kalitesinin tanıtılması ve içimlik çay dışındaki ürünlere endüstriye işlenebilirliğinin değerlendirilmesi amaçlanmıştır.

Anahtar kelimeler: Çay, Çay kalitesi, Doğu Karadeniz Bölgesi, Katma değer

\section{INTRODUCTION}

Tea is one of the most consumed food substances in the world and is the second bevegare after water among soft drinks (Food and Agriculture Organization, 2018). It is estimated that the World's black tea production will increase by $2.2 \%$ annually in the next decade and will reach 4.4 million tons in 2027 (FAO, 2018). China is the world's largest tea producer with an annual production of 1.9 million tons which yield supply more than $38 \%$ of the world. India, the second largest producer, produced 1.2 million tons in 2013, followed by Kenya, Sri Lanka and Turkey (Ministry of Agriculture and Forestry, 2015).

Tea is an industrial plant in the Eastern Black Sea Region of Turkey. The climate, morphology and soil fertility are suitable for growing tea, and moreover tea agriculture and trade is great importance in the economy of the region (Ministry of Agriculture and Forestry, 2019). About 40 thousand people labor in the tea sector with salary and 200 thousand the producer contribute to the family budget (Alikılıc, 2016).

Tea, which has become the second most consumed beverage worldwide, has led to the exploration of its potential benefits on health. Generally, on the basis of processing the leaves, tea can be divided into the non-fermented green and white teas, semi fermented oolong tea and fully fermented black tea (Muniandy et al., 2016).

Green tea leaves are a rich source of flavanols and flavonols and its primary component is catechin. Green tea also contains other other phenolic acids such as gallic acid, chlorogenic acid and caffeic acid, and flavonols such as kaempferol, myricetin and quercetin. Black tea has a lower amount of flavonols (catechin and catechin derivatives), whereas these catechin or/and derivatives conversion into theaflavins and thearubigins during tea fermentation. (Gondoin et al., 2010).

The components of tea leaf in food, nutrition and pharmaceutical products have attracted considerable attention due to the mentioned chemical components. The health benefits of tea leaves have proved such as anticarcinogenic, antibacterial, antioxidant and anti-inflammatory (Reygaert, 2017; Orhan et al, 2019; Zaiter et al, 2016). However, it has been observed that our people can benefit from these valuable ingredients when they consume tea as a beverage. It is considered to be a major deficit in the processing of tea plants into products other than tea beverage. For this reason, in our study, the quality of the regional teas was compared to other world teas and 
the studies in our country regarding the non-tea product's market were compiled.

\subsection{Tea Plant and Historical Development of} Tea

The tea plant, known as Camellia sinensis (L.) O. Kuntze, is a perennial, evergreen and leafy crop (Carloni et al., 2013). Among historical sources, it is commonly believed that tea originated in China and cultivated for more than 2000 years (Baruah, 2017). Based on the morphological characteristics, cultivated tea has three variates, viz. Chinese tea (Camellia thea sinensis), Assam tea (Camellia thea assamica) (Meegahakumbura at al. 2016). The tea grown in Turkey, is mainly Chinese and Indian hybrids (Eroz and Bozok, 2018). Food and Agriculture Organization of the United Nations (2018) was reported that the word area harvested tea has surpassed 4.20 million hectares, and world total tea production has approached 6.34 million tons.

Table 1. World Production of Tea: Top on Producer (FAO, 2018)

\begin{tabular}{ll}
\hline Countries & Production (Tonnes) \\
\hline China & $2,610,400$ \\
India & $1,344,827$ \\
Kenya & 442,990 \\
Sri lanka & 303,840 \\
Turkey & 270,000 \\
Vietnam & 270,000 \\
Indonesia & 141,342 \\
Iran & 109,357 \\
Myanmar & 109,043
\end{tabular}

Japan

83,052

The first attempt to produce tea in our country was made with tea seeds and saplings from Chine which sowed in Bursa province in 1888. However, it was observed that the climate of the region is not suitable (Anonymous, 2016). Rize province and Borcka district were chosen pilot region after the First World War. Nowadays, it is the most convenient and fertile land for tea cultivation in Turkey where from the border district of Georgian up to Araklı district (Alikılic, 2016). While Turkey ranks 7 th in the global area harvested tea among countries of the World, it is the 5th in terms of tea production. In addition, it ranks first in the world with annual tea consumption of 3.5 kilograms per person (Anonymous, 2017).

\subsection{Kind of Tea}

Today, there are many varieties of tea commercially available however all of these tea types are produced from the leaves and buds of the Camellia sinensis L. plant. The differences between the produced teas are occurred by plant growing conditions, harvesting procedures and applying different processing techniques to fresh tea leaves and shoots (Salman \& Ozdemir, 2018).

Depending on the processing and harvest differences, teas classified into three major types: black, green and oolong tea but, there are also different teas such as white and pu-erh tea. The production steps of different teas are schematized in Figure 1 (Salman et al, 2015). 


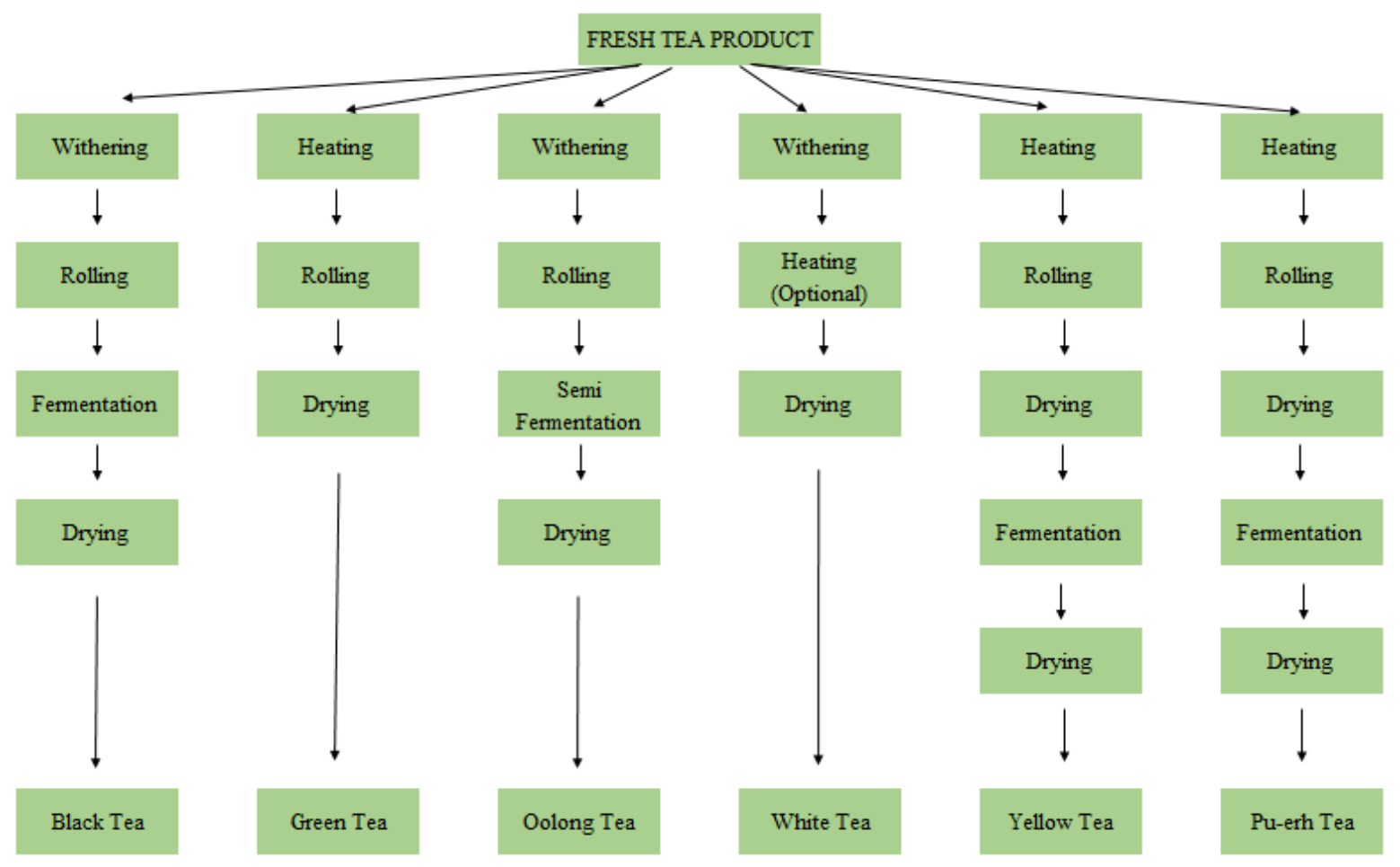

Figure 1. The basic manufacturing stage of the different teas

Green tea is originating from China and Japan which is widely consumed as a soft drink (Yoshida et al., 1999). To produce green tea, leaves are firstly steamed which this step kills the enzyme polyphenol oxidase to maintain its green color, then rolled and dried. Green tea is an important source of polyphenols having a positive effect on human health with non-implementation of the fermentation process. (Chacko et al. 2010; Cimen, 2014). It includes catechins which is the main flavonoid in green tea.

Black tea is about $78 \%$ of the tea production worldwide (Sang et al. 2011) and the production of it is characterized by withering, curling, oxidation and drying processes are applied. Most of the catechins turn into theaflavins and thearubigins with polymerizing during the oxidation step (Kacar, 2010). Theaflavins and thearubigins are flavonoids which have highly bioactive properties.
Oolong tea is produced by semi fermentation of tea leaves and it gives a taste between black and green tea (Fanaro et al., 2012). In this way, it contains catechins, which are the primary phenolics contained in green tea, and products such as theaflavin and thearubigins, which are secondary phenolics contained in black tea (Benzie \& Szeto, 1999).

\subsection{Bioactive Compounds Affecting Tea Quality}

The polyphenols are the predominant constituents of green tea which may about $30 \%$ of dry weight, of this accounting for more than $70 \%$ are the flavanols (Chacko et al., 2010; van der Hooft et al., 2012; Zhao et al., 2011). The major flavanols in the structure of the fresh tea leaves are catechins and catechin derivatives (catechin gallates). These are divided into catechin (C), epicatechin (EC) and epigallocatechin (EGC) and epicatechingallate 
(ECG) and epigallocatechingallate (EGCG) (Chaudhury et al., 2017; Saglam \& Turkyilmaz, 2007). These compounds undergo condensation during the production of black tea and turn into theaflavin compounds, which have a larger molecular structure. Therefore, catechin content is higher in fresh tea leaves and unoxidized teas.

It was reported that fresh green tea leaves have mainly four kinds of catechins: epigallocatechingallate (EGCG), epigallocatechin (EGC), epicatechingallate (ECG), and epicatechin (EC). EGCG is the dominant catechin present in tea leaves and accounts for $30 \%$ to $60 \%$ (Zhang et al., 2019). The beneficial effects of green tea such as antioxidant, anti-inflammatory, antimutagenic, anticancer, anti-carcinogenic, antiangiogenic, apoptotic are attributed to catechins (Lorenzo et al., 2016; Monajjemi et al., 2011; Sahin \& Ozdemir, 2006).

In addition, thanks to its high antioxidant properties, it is considered as a natural additive that can be used to prevent lipid oxidation especially in the production of fatty foods (Gadkari \& Balaraman, 2015).

Total catechin contents of Black Sea region and different country green teas are given in Figure 2 (Balci \& Ozdemir, 2016; Saglam \& Turkyilmaz, 2007; Wang et al., 2000; Yashin et al., 2011). It is known that the teas produced under different brands in our country are the Black Sea region teas. Total catechin values in Turkish teas were found to be considerably higher than some country teas and also to be equivalent. Similarly, when looking at the black tea total catechin values, it is seen that the same table is exhibited in Figure 3 (Alasalvar et al., 2013; Lee et al., 2019; Ofluaolu, 2019; Saglam \& Turkyilmaz, 2007; Wang et al., 2003; Yashin et al., 2011). This table reflects the possibility of using the catechin components of Turkish teas in different sectors.

\section{Total Catechin Content (\%) of Some Regions and Foreign Green Teas}

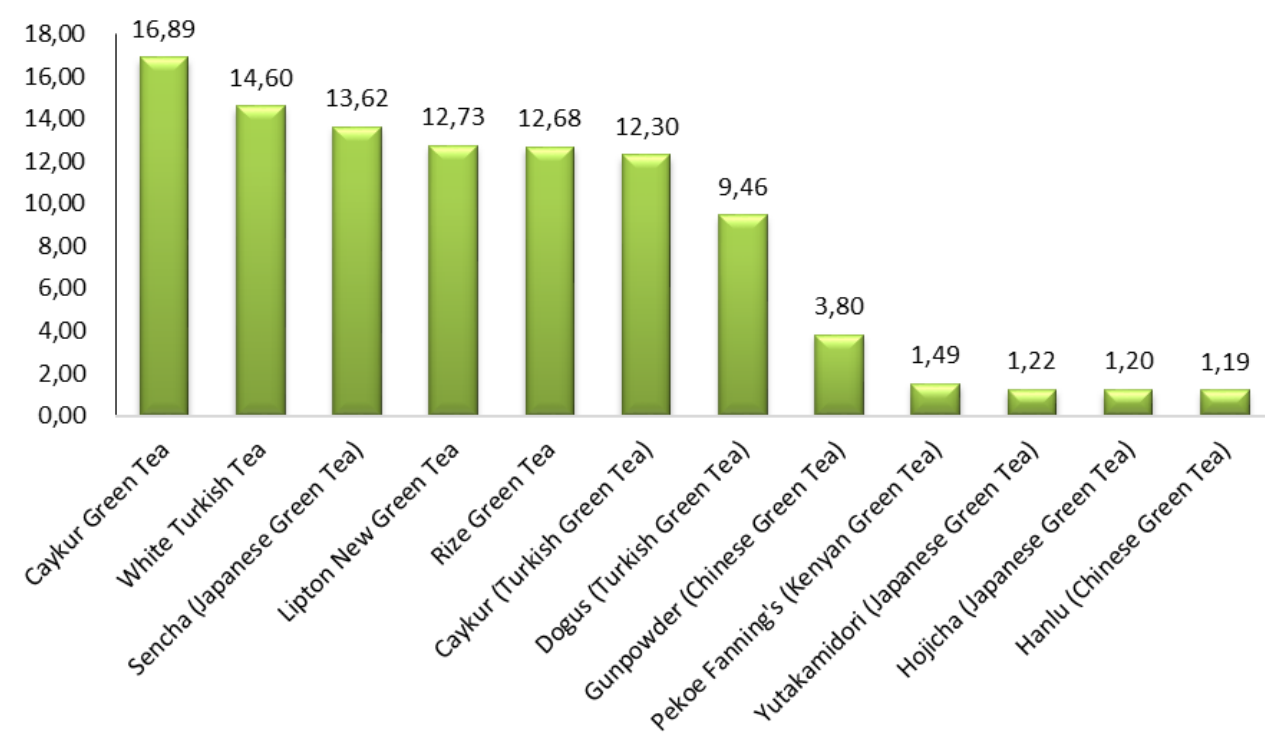

Figure 2. Total Catechin Content (\%) of Some Regions and Foreign Green Teas 


\section{Total Catechin Content (\%) of Some Regions and Foreign Black Teas}

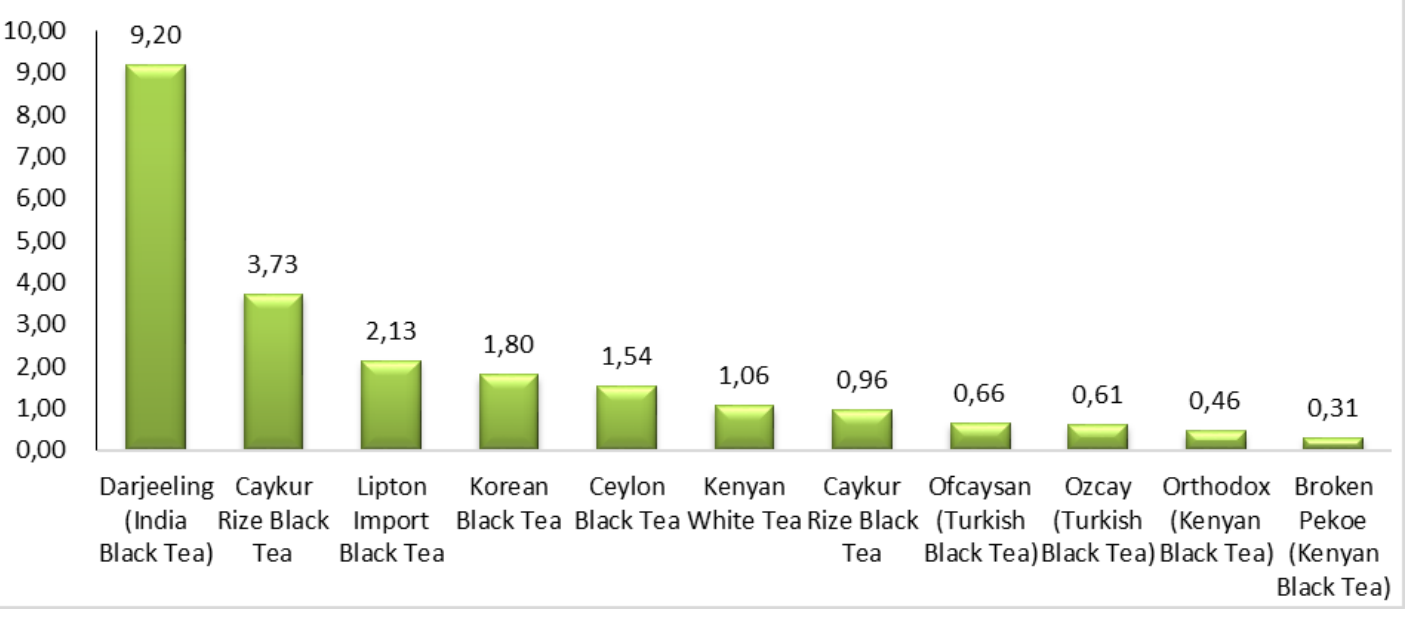

Figure 3. Total Catechin Content (\%) of Some Regions and Foreign BlackTeas

Black tea contains various compounds which influence the flavor and taste of tea brews. In determining the quality characteristics, the most important of these are theaflavins (TF), thearubigins (TR), catechins, some other flavonoids, volatile aroma compounds, caffeine, water-soluble solids (extract) and the amount of cellulose etc. (Ofluoglu, 2019; Yao et al., 2006). Theaflavins (TF) and thearubigins (TR) are subclass flavanolos formed by the polymerization and oxidation of catechins in the presence of polyphenol oxidase (PPO) and peroxidase (POD) enzymes (Imran et al., 2018; Obanda et al., 2001). As a result of oxidation in green tea leaves, they are highly formed in black tea. There are commonly four major types of theaflavin classified as theaflavin (TF1), theaflavin-3-gallate (TF2A), theaflavin-3'gallate (TF2B) and theaflavin-3, 3'-digallate (TF3) (Imran et al., 2018; Pereira-Caro et al., 2017).

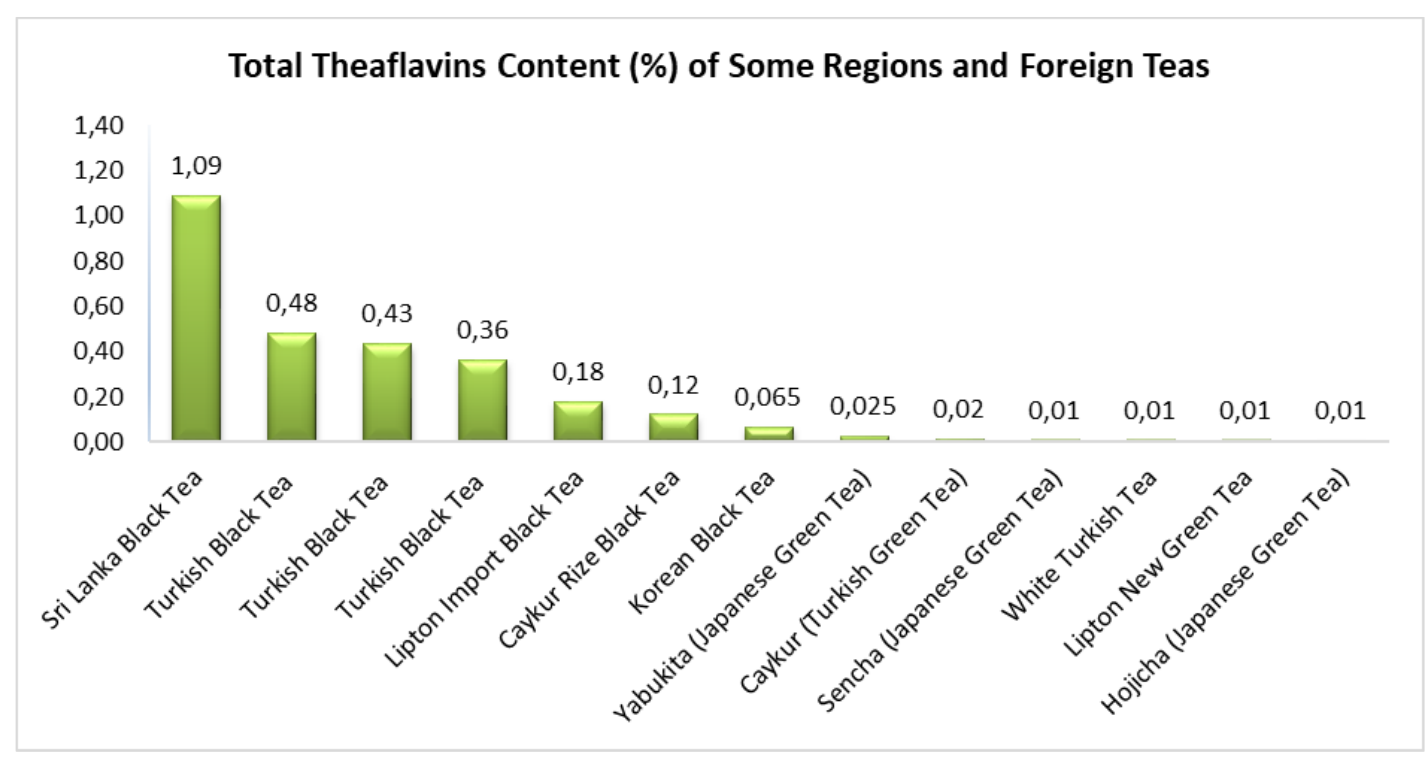

Figure 4. Total Theaflavins Content (\%) of Some Regions and Foreign Teas 
In our study, especially Theaflavins (TF) and thearubigins (TR) which gives different characteristic features to tea beverage is emphasized.TR is more chemically heterogeneous and brown-reddish while TF is bright and orange red. TF, whose amount in dried black tea does not exceed $2 \%$, gives the tea astringency, brightness, color and vitality. However, TR, which makes up $10-15 \%$ of dry tea weight, is responsible for mouth fullness, taste and color (Bonnely et al., 2003; Haslam, 2003; Obanda et al., 2001; Wright et al., 2002).

The total theaflavins contents of the regional teas were compared with the teas of different countries is given in Figure 4 (Abeywickrama et al., 2011; Erol et al., 2010; Kelebek, 2016; Lee et al., 2019;
Saglam \& Turkyilmaz, 2007; Yashin et al., 2011). Based on the compiled data, the theaflavins content of the regional teas was generally higher than the others except for Sri Lanka tea. Further, these components are oxidation product which was found in black teas more than green teas. Tearubins content in Turkish teas was exhibited high value approximate $11 \%$ after Sri Lanka tea (Abeywickrama et al., 2011; Alam et al., 2018; Alasalvar et al., 2013; Bhuyan et al., 2015; Ozdemir et al., 2019; Owuor et al., 2008; Yao et al., 2006). And also for these components, it has been observed that our country's teas compete with world teas in terms of component quality.

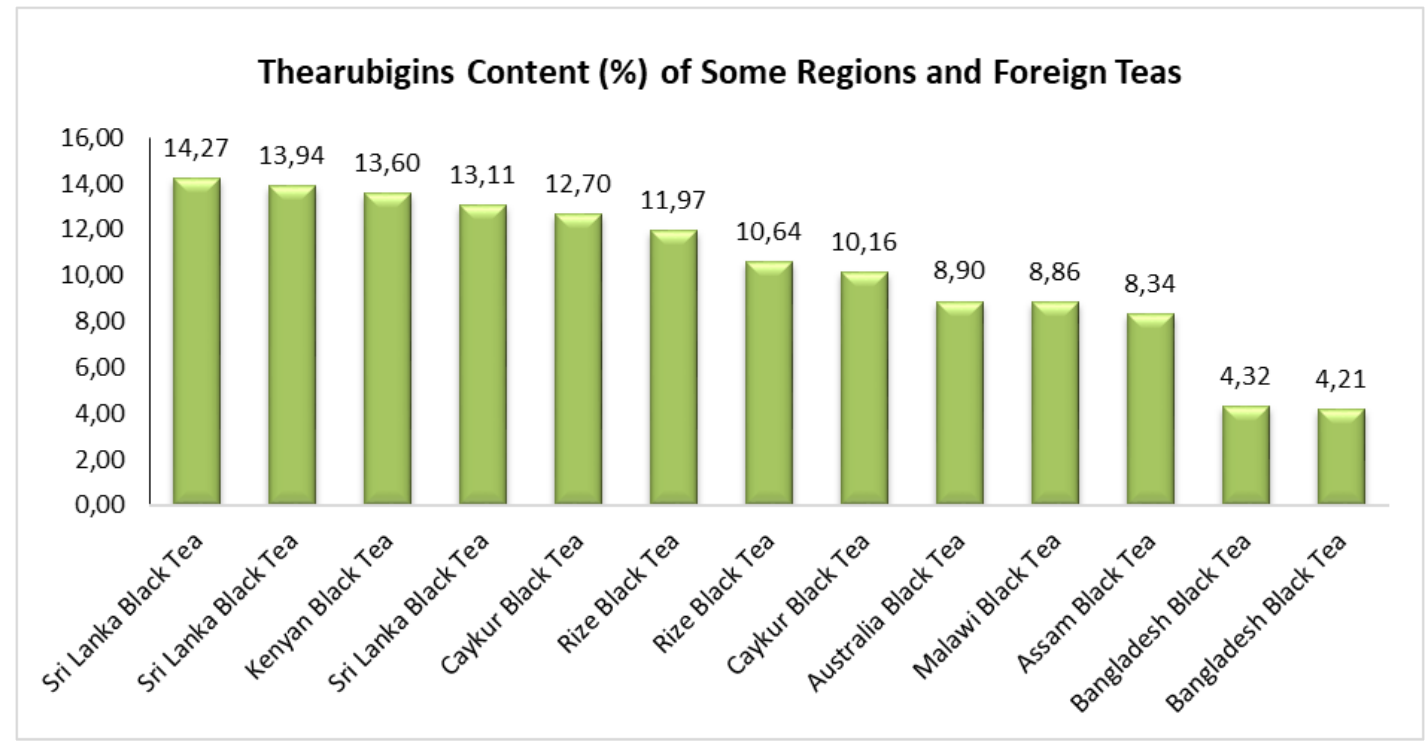

Figure 5. Thearubigins Content (\%) of Some Regions and Foreign Teas

Caffeine, which of chemical formula $\mathrm{C}_{8} \mathrm{H}_{10} \mathrm{~N}_{4} \mathrm{O}_{2}$, belongs to a family of alkaloid and is mostly obtained from coffee, cocoa beans and tea leaves (Abidi et al., 2020). The caffeine content of the fresh tea leaf varies according to the genetic characteristics, soil conditions and harvest periods just like other compounds (Vatan et al., 2000). In the world, $55 \%$ of total caffeine is obtained from synthetic sources and $45 \%$ from natural sources like as decaffeinated coffee and tea wastes. Its pure form is colorless odorless white powder and has intense bitterness (Wanyika et al., 2010). Caffeine consumption is very common due to its several benefits stimulating the nervous system and 
increasing concentration and focus (VillanuevaBermejo et al., 2017).

Caffeine is primarily used in pharmaceuticals and chemistry industries in addition to this used in the food industry to produce caffeinated beverages and as a flavoring in the production of foodstuff (Pradhan et al., 2017). Pure caffeine is a very expensive product with high added value. As can be seen in Figure 6, the caffeine content of our region's teas compete with other country teas (Abeywickrama, 2011; Erol et al., 2010; Komes et al., 2009; Orhan et al., 2019; Ozdemir et al., 2018; Saglam \&Turkyilmaz, 2010). For this reason, it is thought in our country as it is applied in the world that caffeine can be obtained both from the evaluation of tea wastes and decaffeinated tea production.

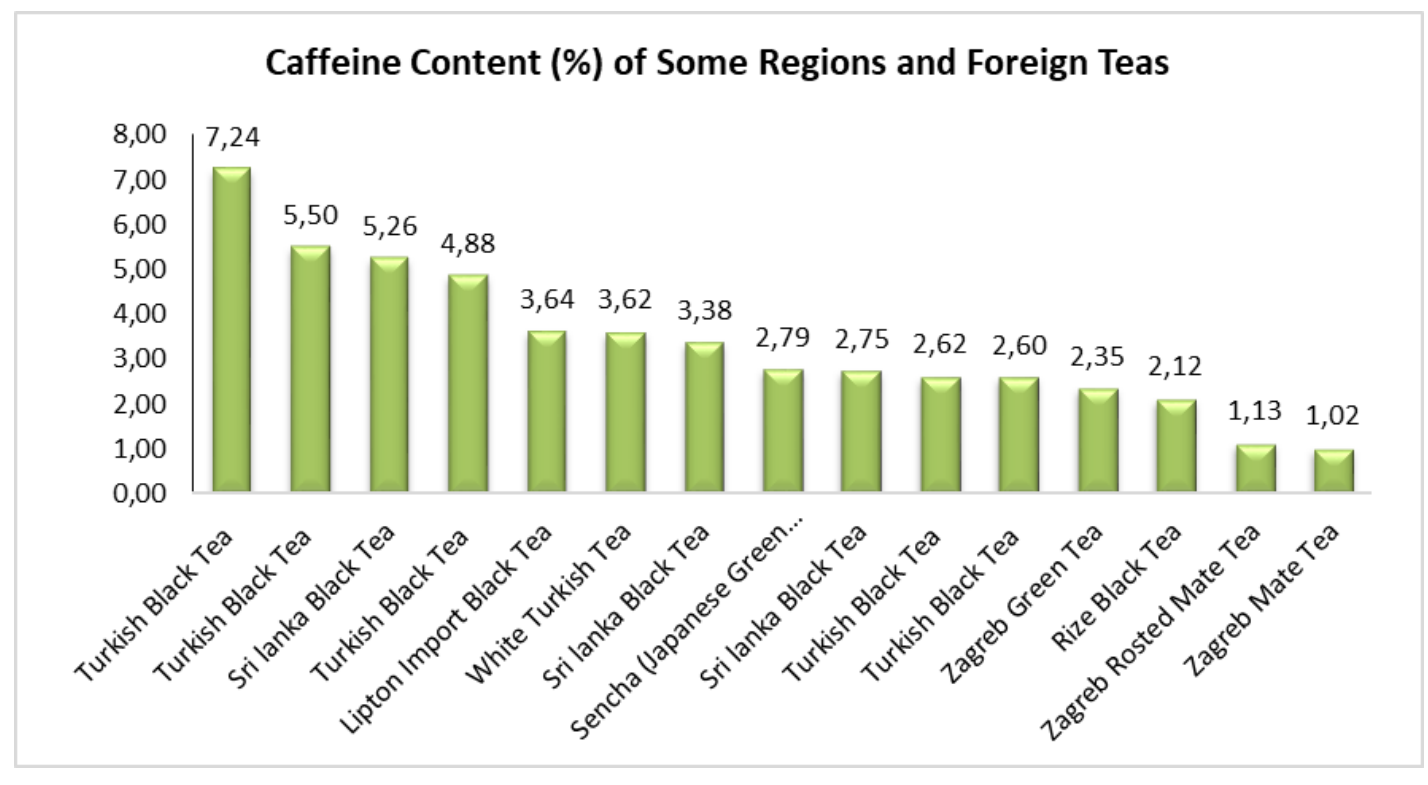

Figure 6. Caffeine Content (\%) of Some Regions and Foreign Teas

\subsection{Available Tea and Tea Products in Our Country}

In our country, as a result of the market researches, it was seen that mainly dry tea is produced and these are packed in different sizes and offered for sale. Cold tea, tea flavored cold drink, have been known since the beginning of the 1900s in the World. Nevertheless, it is consumed as a new tea product in our country's market in recent years. Likewise, instant tea production has gained speed in recent years. These are followed by the tea cologne produced by local companies, and it was also observed that in 2019, ÇAYKUR tried to enter the non-tea products market by producing tea powder. In addition, looking for developments in literature, Ozdemir et al. (2019) produced oolong tea with collected tea from Rize region. The partial oxidation step of oolong tea is complex than black tea by this means it contains both catechins and oxidation products such as TF and TR, hereby it has high antioxidant activity compared to green and black tea. The researchers stated that they foresaw that price of this tea will be $80-100$ Turkish lira/ kg tea.

Tarhan (2017) produced kombucha tea using raw materials such as black tea, green tea, sage and coffee. Kombucha tea is a traditional fermented 
beverage which have a slightly sweet and acidic flavour. This tea, which is widely consumed in the world, is newly recognized in our country and 500 $\mathrm{ml}$ of it is sold for about $35 \mathrm{TL}$ in the boutique market (Anonymous, 2020a). In another study, Us (2016) obtained catechin and caffeine extracts with classical and ultrasonic extraction method using different parameters from green teas. Catechin and caffeine are valuable products used especially in the food and pharmaceutical industry. It is thought that our position in the market will be better if they can be obtained pure and can be created an opportunity to apply to the industry.

\subsection{Available Tea and Tea Products in The World}

In the world, tea and tea products are consumed frequently in industries such as pharmaceuticals, cosmetics, food and health. In addition to the different tea compositions or forms, the products obtained by isolation of the valuable bioactive compounds in the tea increase the added value of the tea. Tea and tea products of different brands offered for sale in the world and their average prices are given in Table 2 (Anonymous, 2020b; 2020c; 2020d).

It has been seen that valuable bioactive components in tea were utilized in many different sectors in addition to tea beverage when we look at the table. These products are used as a food or drug supplement thanks to the effects of strengthening the immune system, burning fat and helping to weaken. It is not only limited to these, but its usage areas also range from chemistry to the cosmetic sector. Also, when looking at the prices of these products, it is clearly seen that these prices are more than several times the price of almost 1 $\mathrm{kg}$ of dry tea.

This table displays that our country should be processed tea into different products with a high added value apart from using tea as a beverage.

Table 2. Different tea and tea products in the foreign market and their price

\begin{tabular}{|c|c|}
\hline Products & Price \\
\hline Decaffeinated tea, $93.5 \mathrm{~g}$ & $4.99 \$$ \\
\hline Green Tea Cologne ,120 ml & $25.40 \$$ \\
\hline $\begin{array}{l}\text { EGCg Green Tea Extract } 400 \mathrm{mg}, 90 \\
\text { Caps }\end{array}$ & $9.97 \$$ \\
\hline $\begin{array}{l}\text { L-Theanine } 100 \mathrm{mg} \text { with Decaf Green } \\
\text { Tea }\end{array}$ & $17.44 \$$ \\
\hline $\begin{array}{l}\text { Theaflavin Standardized Extract } 30 \\
\text { Vegetarian Capsules }\end{array}$ & $13.50 \$$ \\
\hline Caffeine Pills 200mg, 120 Caps & $10.00 \$$ \\
\hline Sigma-Aldrich Synthetic Caffeine, $5 \mathrm{~g}$ & $25.70 €$ \\
\hline $\begin{array}{l}\text { Sigma-Aldrich } \quad \text { Catechin } \\
\text { standard, } 5 \mathrm{mg}\end{array}$ & $291.00 €$ \\
\hline The Green Tea Seed Eye Cream 30ml & $17.49 \$$ \\
\hline $\begin{array}{l}\text { Sigma-Aldrich } \quad \text { L-Theanine } \geq 98 \% \\
\text { (HPLC), } 100 \mathrm{mg}\end{array}$ & $121.00 €$ \\
\hline
\end{tabular}

\section{RESULTS AND CONCULISION}

The present study was carried out to review the quality of the regional teas and their applicability to industrial products other than drinking tea. The amount of important quality criteria (catechin, caffeine, teaflavin, tearubugin) of black and green teas produced from the regional teas were found to be equivalent when compared to the world teas. Considering the tea production and consumption in our country, it has been observed that the amount of biologically active componenets that can be isolated from tea and tea wastes is 
considerably important. However, it has been observed that Turkish tea or its ingredients are not processed into many different products. As a result, it was determined that although Turkey ranks 7 th in the production of fresh tea in the world

\section{REFERENCES}

Abeywickrama, K. R. W., Ratnasooriya, W. D., \& Amarakoon, A. M. T. (2011). Oral hypoglycaemic, antihyperglycaemic and antidiabetic activities of Sri Lankan Broken Orange Pekoe Fannings (BOPF) grade black tea (Camellia sinensis L.) in rats. Journal of ethnopharmacology, 135(2), 278-286.

Abidi, S., Gilani, U., \& Zehra, R. (2020). Extraction and analysis of caffeine from various brands of tea leaves marketed in Pakistan. Journal of Pharmacognosy and Phytochemistry, 9(1), 0910.

Alam, K. M., Chowdhury, S., Akhter, R., \& Uddin, M. S. (2018). Qualitative and quantitative evaluation for caffeine, phenolic compounds and nutrient elements in six marketed brands of Kazi and Kazi tea produced in Bangladesh. Journal of Pharmacognosy and Phytochemistry, 7(3), 24602467.

Alasalvar, C., Pelvan, E., Özdemir, K. S., Kocadağlı, T., Mogol, B. A., Paslı, A. A., ... \& Gökmen, V. (2013). Compositional, nutritional, and functional characteristics of instant teas produced from low-and high-quality black and our tea components quality are equivalent to the world teas, there is not enough orientation nontea products in our country. And also, it is thought that tea should be processed into different products in order to enter the non-tea products market.

teas. Journal of agricultural and food chemistry, 61(31), 7529-7536.

Alikılıç, D. (2016). Çay’ın Karadeniz Bölgesi İçin Önemi Ve Tarihi Seyri, Karadeniz Incelemeleri Dergisi, 11, 21, 269-280.

Anonymous. (2017). Retrieved May 23, 2020 from

http://www.caykur.gov.tr/Pages/Yayinlar/YayinD etay.aspx ?temType $=5 \&$ ItemId $=401$.

Anonymous. (2019). Çaykur İstatistik Bülten. Retrieved May 23, 2020 from http://www.caykur.gov.tr/CMS/Design/Sources/ Dosya/Yayinlar/201.pdf. 10 Aralık 2019

Anonymous. (2020a) Retrieved May 23, 2020 from

https://www.fermentemutfagim.com/organik-

kombucha-

cayi?gclid=CjwKCAjwk6P2BRAIEiwAfVJ0rA0 oGxLAYwiAsAi07F20a6KFO-

RrUGDtVm6BSPMhQe2IkNXZDuAyGRoCQU YQAvD_BwE

Anonymous. (2020b). Retrieved May 25, 2020 from https://www.lipton.com/us/en/ourteas/decaf-black-tea.html. 
Anonymous. (2020c). Retrieved May 25, 2020 from https://www.amazon.com/gp/offeristing.

Anonymous. (2020d). Retrieved May 25, 2020 fromhttps://www.sigmaaldrich.com/catalog/produ ct/sial/c0750?lang=en\&region=TR.

Balci, F., \& Ozdemir, F. (2016). Influence of shooting period and extraction conditions on bioactive compounds in Turkish green tea. Food Science and Technology, 36(4), 737-743.

Baruah, P. (2017). Wild Teas of Assam and North East India. Journal of Tea Science Research, 7(7).

Benzie I.,F., F. \& Szeto Y., T. (1999). Total antioxidant capacity of teas by the ferric reducing antioxidant power assay. J Agric Food Chem, 47, 633-636.

Bhuyan, L. P., Borah, P., Sabhapondit, S., Gogoi, R., \& Bhattacharyya, P. (2015). Spatial variability of theaflavins and thearubigins fractions and their impact on black tea quality. Journal of food science and technology, 52(12), 7984-7993.

Bonnely, S., Davis, A.L., Lewis, J.R., \&Astill, C. (2003). A Model Oxidation System To Study Oxidised Phenolic Compounds Present In Black Tea, Food Chemistry, 83, 485-492.

Carloni P., Tiano L., Padella L., Bacchetti T., Customu C., Kay A. \& Damiani E. (2013). Antioxidant Activity of White, Green and Black Tea Obtained from the Same Tea Cultivar. Food Research International, 53, 900-908.
Chacko, S. M., Thambi, P. T., Kuttan, R., \& Nishigaki, I. (2010). Beneficial effects of green tea: a literature review. Chinese medicine, 5(1), 13.

Chaudhury, S., Roy, P., \& Dasgupta, S. (2017). Green tea flavanols protect human $\gamma \mathrm{B}$-crystallin from oxidative photodamage. Biochimie, 137, 4655.

Çimen, K., 2014. Türkiye' de Çay Yetiştiriciliği ve Çay Sanayii, Master's thesis, Istanbul Technical University].

Erol, N. T., Sarı, F., \& Velioglu, Y. S. (2010). Polyphenols, alkaloids and antioxidant activity of different grades Turkish black tea. Gida,35(3), 161-168.

Eröz, S. S., \& Bozok, D. (2018). Çay Turizmi ve Rize İli Potansiyeli. Third Sector Social Economic Review, 53(3), 1159. Eröz, S. S., \& Bozok, D. (2018). Çay Turizmi ve Rize İli Potansiyeli. Third Sector Social Economic Review, 53(3), 1159.

Fanaro, G. $\quad$ B., Duarte, R. C., Santillo, A. G., Silva, M. P., Purgatto, E. \& Villavicencio, A. L. C. H. (2012). Evaluation of $\gamma$-radiation on oolong tea odor volatiles. Radiat. Phys. Chem. 81(8):1152-1156.

FAO. (2018). Food and Agriculture Organization of the United Nations. Rome, Italy. http://www.fao.org/faostat/en/\#data/QC/visualize

Gadkari, P., V., \& Balaraman, M. (2015). Catechins: Sources, extraction and encapsulation: 
A review. Food and Bioproducts Processing, 93, 122-138.

Gondoin, A., Grussu, D., Stewart, D., McDougall, G., J. 2010. White and green tea polyphenols inhibit pancreatic lipase in vitro. Food Research International, 43, 5, 1537-1544.

Haslam, E., 2003. Thoughts on Thearubigins, Phytochemistry, 64, 61-73.

Imran, A., Arshad, M. U., Arshad, M. S., Imran, M., Saeed, F., \& Sohaib, M. (2018). Lipid peroxidation diminishing perspective of isolated theaflavins and thearubigins from black tea in arginine induced renal malfunctional rats. Lipids in health and disease, 17(1), 157.

Kacar, B. (2010). Çay Bitkisi Biyokimyası Gübrelenmesi İşleme Teknolojisi. Nobel Yayınları, 356 s, Ankara.

Kelebek, H. (2016). LC-DAD-ESI-MS/MS characterization of phenolic constituents in Turkish black tea: Effect of infusion time and temperature. Food chemistry, 204, 227-238.

Komes, D., Horzic, D., Belscak, A., Kovacevic Ganic, K., \& Bljak, A. (2009). Determination of caffeine content in tea and maté tea by using different methods. Czech J. Food Sci, 27, 213-216.

Lee, M. K., Kim, H. W., Lee, S. H., Kim, Y. J., Asamenew, G., Choi, J., ... \& Kim, J. B. (2019). Characterization of catechins, theaflavins, and flavonols by leaf processing step in green and black teas (Camellia sinensis) using UPLC-DAD-
QToF/MS. European Food Research and Technology, 245(5), 997-1010

Lorenzo, J. M., \& Munekata, P. E. S. (2016). Phenolic compounds of green tea: Health benefits and technological application in food. Asian Pacific journal of tropical biomedicine, 6(8), 709719.

Meegahakumbura, M.K., Wambulwa, M.C., Thapa, K.K., Li, M.M., Möller, M., Xu, J.C., Yang, J.B., Liu, B.Y., Ranjitkar, S., Liu, J., Li, D.Z. \& Gao, L.M. (2016). Indications for Three Independent Domestication Events for the Tea Plant (Camellia sinensis (L.) O. Kuntze) and New Insights into the Origin of Tea Germplasm in China and India Revealed by Nuclear Microsatellites. PLoS ONE.. doi:10.1371/journal.pone.0155369

Ministry of Agriculture and Forestry, 2019. Global tea consumption and production driven by robust demand in China and India" Retrieved December 25 , 2019 from http://www.fao.org/news/story/en/item/1136255/i code/

Ministry of Agriculture and Forestry. (2015). World Tea Production and Trade. Current and Future Development. Retrieved December 25, 2019 from http://www.fao.org/3/a-i4480e.pdf.

Ministry of Agriculture and Forestry. (2019). Tarım Ürünleri Piyasaları, ÇAY. Retrieved December 25, 2019 from https://arastirma.tarimorman.gov.tr/tepge/Belgele r/PDF. Son erişim tarihi: 24 Şubat 2019. 
Monajjemi, M., Khosravi, M., Honarparvar, B., \& Mollaamin, F. (2011). Substituent and solvent effects on the structural bioactivity and anticancer characteristic of catechin as a bioactive constituent of green tea. International Journal of Quantum Chemistry, 111(12), 2771-2777.

Muniandy, P., Shori, A. B., \& Baba, A. S. (2016). Influence of green, white and black tea addition on the antioxidant activity of probiotic yogurt during refrigerated storag, Food Packaging and Shelf Life, 8, 1-8.

Obanda, M., Owuor, P. O., \& Mang'oka, R. (2001). Changes in the chemical and sensory quality parameters of black tea due to variations of fermentation time and temperature, Food chemistry, 75, 4, 395-404.

Ofluaolu, P. (2019). Determination of quality characteristics and green tea production from tea leaves grown in different region in Turkey,

Orhan, N., Ekin, H. N., Şüküroğlu, M. K., \& Aslan, M. (2019). In vitro antidiabetic effect, quantitative studies and UPLC-TOF-MS analysis of black tea samples from Turkish market. Marmara Pharmaceutical Journal, 23(3).

Owuor, P. O., Obanda, M., Nyirenda, H. E., \& Mandala, W. L. (2008). Influence of region of production on clonal black tea chemical characteristics. Food Chemistry, 108(1), 263-271.

ÖZDEMIR, F., NADEEM, H. Ş., AKDOĞAN, A., DİNÇER, C., \& Topuz, A. (2018). Effect of altitude, shooting period, and tea grade on the catechins, caffeine, theaflavin, and thearubigin of
Turkish black tea. Turkish Journal of Agriculture and Forestry, 42(5), 334-340.

Pereira-Caro, G., Moreno-Rojas, J. M., Brindani, N., Del Rio, D., Lean, M. E., Hara, Y., \& Crozier, A. (2017). Bioavailability of black tea theaflavins: Absorption, metabolism, and colonic catabolism. Journal of agricultural and food chemistry, 65(26), 5365-5374.

Pradhan, D., Biswasroy, P., Kapil, K., \& Jatin, R. (2017). Qualitative and quantitative analysis of caffeine in some commercial brands of tea consumed in India. Journal of Ayurvedic and Herbal Medicine, 3(4), 200-204.

Reygaert, W. C. (2017). An update on the health benefits of green tea. Beverages, 3(1), 6 .

Saglam, N., \& Turkyilmaz, K. (2007). Ticari olarak piyasada satilan türk ve yabanci kökenli çaylarin bazi fenolik madde ve kafein içeriklerinin belirlenmesi,

http://www.caykur.gov.tr/CMS/Design/Sources/ UnitePCKYSDokumanlari/78_77.pdf.

Şahin, H., \& Özdemir, F., 2006. Yeşil çayın sağlık üzerine etkisi. Türkiye, 9, 24-26.

Salman, S., \& Özdemir, F., 2018. Beyaz Çay: Üretimi, Bileşimi ve Sağlık Üzerine Etkileri. Akademik Gıda, 16, 2, 218-223

Salman, S., Torun, M., Özdemir, F., 2015. Aynı bitkiden lezzeti farklı çaylar. Drinktech Dergisi, 90, 74-78. 
Sang, S., Lambert, J. D., Ho, C. T., \& Yang, C. S. (2011). The chemistry and biotransformation of tea constituents. Pharmacological research, 64(2), 87-99.

Tarhan, K. (2017). Use of different substrate resources in the production of kombucha tea. [Master's thesis, Mediterranean University].

Us, A. A. (2016). Yeşil çaylardan farkli yöntemlerle kateşin ve kafein ekstraksiyonu ve bunlarin saflaştirilmasi için uygun adsorbanlarin belirlenmesi [Master's thesis, Yildiz Technical University].

van der Hooft, J. J., Akermi, M., Ünlü, F. Y., Mihaleva, V., Roldan, V. G., Bino, R. J., ... \& Vervoort, J. (2012). Structural annotation and elucidation of conjugated phenolic compounds in black, green, and white tea extracts. Journal of agricultural and food chemistry, 60(36), 88418850 .

Vatan, Ö., Hasdemir, İ.M., İnci, İ., Bilgi, M. \& Aydın, A. (2000). Kafeinin Su ve Etil Asetat /Kloroform Karışımı arasındaki Dağılma Katsayılarının Ortam Asitliğine Bağlı Olarak Değişimi. DEÜ Mühendislik Fakültesi Fen ve Mühendislik Dergisi, 2, 3, 1-6.

Villanueva-Bermejo, D., Reglero G. \& Fornari, T.(2017). Recent Advances in the Processing of Green Tea Biomolecules Using Ethyl Lactate. a Review. Trends in Food Science and Technology 62, 1-12.

Wang, H., Helliwell, K., \& You, X. (2000). Isocratic elution system for the determination of catechins, caffeine and gallic acid in green tea using HPLC. Food Chemistry, 68(1), 115-121.

Wang, H., Provan, G. J., \& Helliwell, K. (2003). HPLC determination of catechins in tea leaves and tea extracts using relative response factors. Food chemistry, 81(2), 307-312.

Wanyika, H.N., Gatebe, E.G., Gitu, L.M., Ngumba, E.K. \& Maritim, C.W. (2010). Determination of caffeine content of tea and instant coffee brands found in the Kenyan market. Afr. J. Food Sci., 4, 6, 353 - 358.

Wright, L.P., Mphangwe, N.I.K., Nyirenda, H.E., and Apostolides, Z. (2002). Analysis Of The Theaflavin Composition In Black Tea (Camellia Sinensis) For Predicting The Quality Of Tea Produced In Central And Southern Africa, Journal of the Science of Food and Agriculture, 82, 517525.

Yao, L. H., Jiang, Y. M., Caffin, N., D'arcy, B., Datta, N., Liu, X., ... \& Xu, Y. (2006). Phenolic compounds in tea from Australian supermarkets. Food Chemistry, 96(4), 614-620.

Yao, L.H., Jiang, Y.M., Caffin, N., D’Arcy, B., Datta, N., Liu, X., Singanusong, R. \& Xu, Y. (2006). Compositional analysis of teas from Australian supermarkets, Food Chemistry, 94, 115-122.

Yashin, A., Yashin, Y., \& Nemzer, B. (2011). Determination of antioxidant activity in tea extracts, and their total antioxidant content. Am J Biomed Sci, 3(4), 322-335. 
Yoshida, Y., Kiso, M. ve Goto, T., 1999. Efficiency of the Extraction of Catechins from Green tea, Food Chemistry, 67, 429-433.

Zaiter, A., Becker, L., Karam, M. C., \& Dicko, A. (2016). "Effect of particle size on antioxidant activity and catechin content of green tea powders, Journal of food science and technology, 53, 4, 2025-2032.

Zhang, Y., Zhao, T., Deng, J., Zhou, X., Wu, Z., Su, Q., ... \& Yang, Y. (2019). Positive effects of the tea catechin (-)-epigallocatechin-3-gallate on gut bacteria and fitness of Ectropis obliqua Prout (Lepidoptera: Geometridae). Scientific reports, 9(1), 1-9.
Zhao, Y., Chen, P., Lin, L., Harnly, J. M., Yu, L. L., \& Li, Z. (2011). Tentative identification, quantitation, and principal component analysis of green pu-erh, green, and white teas using UPLC/DAD/MS. Food Chemistry, 126(3), 12691277. 